\title{
The transcription factor Sox 10 is a key regulator of peripheral glial development
}

\author{
Stefan Britsch, ${ }^{1,5}$ Derk E. Goerich, ${ }^{2,3,5}$ Dieter Riethmacher, ${ }^{3}$ Reto I. Peirano, ${ }^{2,3}$ Moritz Rossner, ${ }^{4}$ \\ Klaus-Armin Nave, ${ }^{4}$ Carmen Birchmeier, ${ }^{1,6}$ and Michael Wegner ${ }^{2,3,6}$ \\ ${ }^{1}$ Max-Delbrück-Center for Molecular Medicine, D-13122 Berlin, Germany; ${ }^{2}$ Institut für Biochemie, Universität \\ Erlangen-Nürnberg, D-91054 Erlangen Germany; ${ }^{3}$ Zentrum für Molekulare Neurobiologie, D-20246 Hamburg, Germany; \\ ${ }^{4}$ Max-Planck-Institut für Experimentelle Medizin, D-37075 Göttingen, Germany
}

The molecular mechanisms that determine glial cell fate in the vertebrate nervous system have not been elucidated. Peripheral glial cells differentiate from pluripotent neural crest cells. We show here that the transcription factor Sox10 is a key regulator in differentiation of peripheral glial cells. In mice that carry a spontaneous or a targeted mutation of Sox10, neuronal cells form in dorsal root ganglia, but Schwann cells or satellite cells are not generated. At later developmental stages, this lack of peripheral glial cells results in a severe degeneration of sensory and motor neurons. Moreover, we show that Sox10 controls expression of $E r b B 3$ in neural crest cells. ErbB3 encodes a Neuregulin receptor, and down-regulation of ErbB3 accounts for many changes in development of neural crest cells observed in Sox10 mutant mice. Sox10 also has functions not mediated by ErbB3, for instance in the melanocyte lineage. Phenotypes observed in heterozygous mice that carry a targeted Sox10 null allele reproduce those observed in heterozygous Sox $10^{D o m}$ mice.

Haploinsufficiency of Sox10 can thus cause pigmentation and megacolon defects, which are also observed in Sox $10^{\text {Dom }} /+$ mice and in patients with Waardenburg-Hirschsprung disease caused by heterozygous SOX10 mutations.

\{Key Words: Sox10; neuregulin; erbB3; neural crest; glial cells; melanocytes]

Received July 2, 2000; revised version accepted November 16, 2000.

Neural crest cells detach from the dorsal neural tube and migrate over large distances in the embryo, using characteristic pathways. On arrival at their targets, they differentiate to form the majority of the peripheral nervous system, as well as other cell types and tissues including melanocytes (Le Douarin and Kalcheim 1999). Glial cells of the peripheral nervous system are generated by neural crest cells. These glia include satellite cells located in ganglia as well as Schwann cells, which ensheath peripheral axons. The differentiation of glial cells is thought to be regulated by the neurons they accompany. In vitro, transient activation of Notch signaling suffices to suppress the neurogenic differentiation of neural crest cells and accelerates glial differentiation (Morrison et al. 2000; Wakamatsu et al. 2000). Moreover, differentiation of neural crest cells into glia is promoted by Neuregulin-1, an EGF-like factor that activates ErbB receptors (Shah et al. 1994). Melanocytes represent another major derivative of the neural crest. They originate as nonpigmented

\footnotetext{
${ }^{5}$ These authors contributed equally to this work. ${ }^{6}$ Corresponding authors.

E-MAIL cbirch@mdc-berlin.de; FAX 49-30-9406-3765.

E-MAIL m.wegner@biochem.uni-erlangen.de; FAX 49-9131-85-22484.

Article and publication are at www.genesdev.org/cgi/doi/10.1101/ gad.186601.
}

precursors and migrate along characteristic dorso-lateral pathways to the epidermis. Development of the melanocyte lineage has been well studied genetically, as mutations in genes essential for their development cause pigmentation defects easily identifiable in mice and man (Goding 2000).

Sox10 was found because of its sequence homology to transcription factors of the SRY family, which contain a DNA-binding domain of the high mobility group (HMG) box family (Kuhlbrodt et al. 1998a; Wegner 1999). As yet, $>20$ members of the Sox gene family have been identified in mammals, which play important roles in diverse developmental processes such as sex determination, chondrogenic differentiation, or hematopoiesis (Wegner 1999|. Sox10 expression is initiated in neural crest cells as they dissociate from the neural tube, and expression is maintained during neural crest cell migration. Expression continues in the glial and melanocyte lineages, but Sox10 is turned off in many other neural crest cell derivatives (Herbarth et al. 1998; Kuhlbrodt et al. 1998a; Pusch et al. 1998). In the heterozygous state, spontaneous mutations of Sox10 interfere with the development of melanocytes and of the enteric nervous system, causing pigmentation changes and megacolon. Such mutations have been identified in mice, the Dominant megacolon mutation $\left(\right.$ Sox $\left.10^{D o m}\right)$, and in patients afflicted 
with Waardenburg syndrome type 4 (Herbarth et al. 1998; Kuhlbrodt et al. 1998b; Pingault et al. 1998; Southard-Smith et al. 1998, 1999). Moreover, myelination defects in the central and peripheral nervous systems were noted in certain patients with heterozygous Sox10 mutations (Inoue et al. 1999; Pingault et al. 2000; Touraine et al. 2000). In accordance, Sox10 controls expression of myelin protein genes like $P_{O}$ and binds to the $\mathrm{P}_{\mathrm{O}}$ promoter (Peirano et al. 2000). Homozygous Sox $10^{\text {Dom }}$ mutant mice display severe deficits in the peripheral nervous system, which include a lack of enteric ganglia and a severe hypoplasia of the sympathetic ganglion chain (Herbarth et al. 1998; Southard-Smith et al. 1998; Kapur 1999).

The spontaneous Sox10 mutations characterized are nonsense or frameshift mutations. For instance, a frameshift mutation generated the murine Sox $10^{\text {Dom }}$ allele, which encodes a protein in which the N-terminal 193 amino acids of Sox10, including the HMG box, are preserved and fused to 99 amino acids encoded by a different reading frame (Herbarth et al. 1998; Southard-Smith et al. 1998). Similarly, known human Sox10 mutations are predicted to generate truncated proteins that retain functional sequences, such as a homodimerization domain, a synergy region, or the DNA-binding domain (Kuhlbrodt et al. 1998b; Pingault et al. 1998; Bondurand et al. 1999; Inoue et al. 1999; Southard-Smith et al. 1999; Peirano and Wegner 2000; Pingault et al. 2000; Touraine et al. 2000). Indeed, the proteins encoded by many of the spontaneously mutated Sox10 alleles have unaltered DNAbinding properties. It was therefore suggested that the developmental defects observed in Waardenburg-Hirschsprung disease are caused by a dominant-negative action of the mutant Sox10 protein (Kuhlbrodt et al. 1998b; Pingault et al. 1998; Southard-Smith et al. 1999).

ErbB3 encodes a member of the family of EGF receptor tyrosine kinases, binds Neuregulins with high affinity, and requires ErbB2 as a coreceptor for signaling in vivo (Adlkofer and Lai 2000; Garratt et al. 2000). The expression of ErbB3, like that of Sox10, is initiated in neural crest cells as they dissociate from the neural tube and is maintained in glia but downregulated in other derivatives of neural crest cells (Meyer and Birchmeier 1995; Meyer et al. 1997). Additional, nonoverlapping expression domains of Sox10 and ErbB3 in other tissues exist. $\mathrm{ErbB3}^{-/-}$mice and other mutants of the Neuregulin signaling system display defects in development of neural crest cells and their derivatives, which include a lack of Schwann cells (Erickson et al. 1997; Riethmacher et al. 1997; Britsch et al. 1998; Morris et al. 1999; Woldeyesus et al. 1999; Garratt et al. 2000; Wolpowitz et al. 2000). An additional, conspicuous phenotype in such mice is the degeneration of sensory and motor neurons. ErbB3 is required cell autonomously for the development of Schwann cells, but not for survival of sensory and motor neurons (Riethmacher et al. 1997). The neurodegeneration observed in such mutant mice is thus caused by indirect mechanisms.

We report here the generation of a targeted Sox10 mutation in mice, in which the complete open reading frame of Sox10 is replaced by lacZ sequences (Sox $\left.10^{\text {lacZ }}\right)$. In a heterozygous state, the $\operatorname{Sox} 10^{1 a c Z}$ mutation causes phenotypes that reproduce those of the spontaneous Sox $10^{D o m}$ allele. Thus, haploinsufficiency can account for megacolon and pigmentation defects. In homozygous Sox10 mutant mice, sensory neurons form in dorsal root ganglia, but satellite cells or Schwann cells do not develop, demonstrating a key role of this transcription factor in the development of peripheral glial cells. The similarities in expression patterns of Sox10 and ErbB3 prompted us to investigate a genetic interaction between the two genes. We demonstrate here that appropriate ErbB3 expression in neural crest cells, but not in other tissues like muscle or skin, requires Sox10. In accordance, Sox10 and ErbB3 mutant mice share phenotypes. These include a conspicuous degeneration of sensory and motor neurons. This finding allows us to assign, unequivocally, a trophic function to glial cells in the maintenance of neurons.

\section{Results}

Generation of Sox $10^{\text {lacz }}$ mice

To mutate Sox10, a targeting vector was constructed that deleted the coding sequences and fused lac $Z$ in frame to the Sox10 initiation codon (Fig. 1a). The targeting vector was introduced into ES cells and homologous recombination events were identified (Fig. 1b; data not shown). Mutant ES cells were used to generate chimeras that transmitted the Sox $10^{\text {lac } Z}$ allele to their offspring (see also Materials and Methods). Heterozygous Sox $10^{\text {lacZ }}$ mutant mice were crossed with $\mathrm{C} 3 \mathrm{HeB} / \mathrm{FeJLe}-$ a/a $(\mathrm{C} 3 \mathrm{H})$ mice; this strain was chosen because of its widespread use in the analysis of phenotypes of the Sox10 ${ }^{\text {Dom }}$ allele (Lane and Liu 1984; Herbarth et al. 1998; Southard-Smith et al. 1998, 1999). In the first three backcross generations, heterozygous Sox $10^{\text {lacz }}$ mice were indistinguishable from wild-type littermates. In the fourth generation, they became recognizable by pigmentation defects, and most displayed a white belly spot. Further experiments described here were performed with mice of the fourth or subsequent generations of backcrosses with $\mathrm{C} 3 \mathrm{H}$ mice.

A significant proportion of heterozygous Sox $10^{\text {lacz }}$ mice were lost during the first postnatal weeks. At the time of weaning, heterozygous mice were under-represented, constituting $38.2 \%$ of the progeny (259 animals examined), but perinatally the expected Mendelian ratio was observed. Dissection demonstrated the occurrence of megacolon in a fraction of the heterozygous Sox $10^{1 a c Z}$ animals (data not shown). Megacolon, which reduces postnatal survival, has also been reported previously for heterozygous Sox10 ${ }^{\text {om }}$ mice (Lane and Liu 1984; Southard-Smith et al. 1999). Among offspring of heterozygous intercrosses, no Sox $10^{\text {lacZ }} /$ Sox $10^{\text {lacz }}$ animals were observed. To determine the time of death, embryos were genotyped at various stages of development. Live Sox $10^{\text {lacZ }} /$ Sox $10^{\text {lacZ }}$ embryos were found in ratios close to the expected Mendelian frequencies before and at day 
Britsch et al.
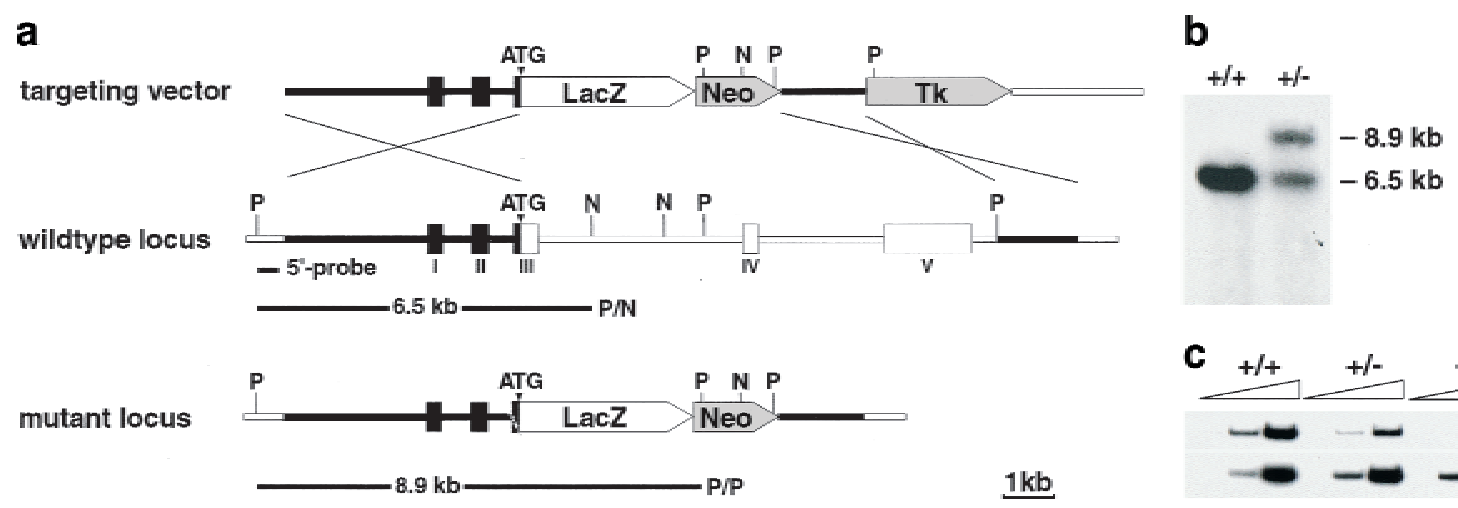

Figure 1. Targeted deletion of Sox10 and expression of the Sox $10^{\text {lacz }}$ allele in mice. (a) Schematic representation of the targeting strategy employed to disrupt the Sox10 gene. Shown are the targeting vector (top), the wild-type Sox10 locus (middle) and the mutated locus after homologous recombination (bottom). Noncoding and coding exons are represented by black or open boxes, respectively. Restriction sites for $\operatorname{SpeI}(\mathrm{P})$ and $N c o \mathrm{I}(\mathrm{N})$ as well as the location of the $5^{\prime}$ probe are indicated. $(b)$ Southern blot analysis of DNA from adult heterozygous $(+/-)$ and wild-type $(+/+)$ mice after digestion with $\mathrm{NcoI} / \mathrm{SpeI}$. The expected size of the fragments detected by the probe used for hybridization are shown (a). (c) RT-PCR analysis of wild-type $(+/+)$, heterozygous $(+/-)$ and homozygous $(-/-)$ embryos at E12.5 using primers specific for the coding region of Sox10. Results
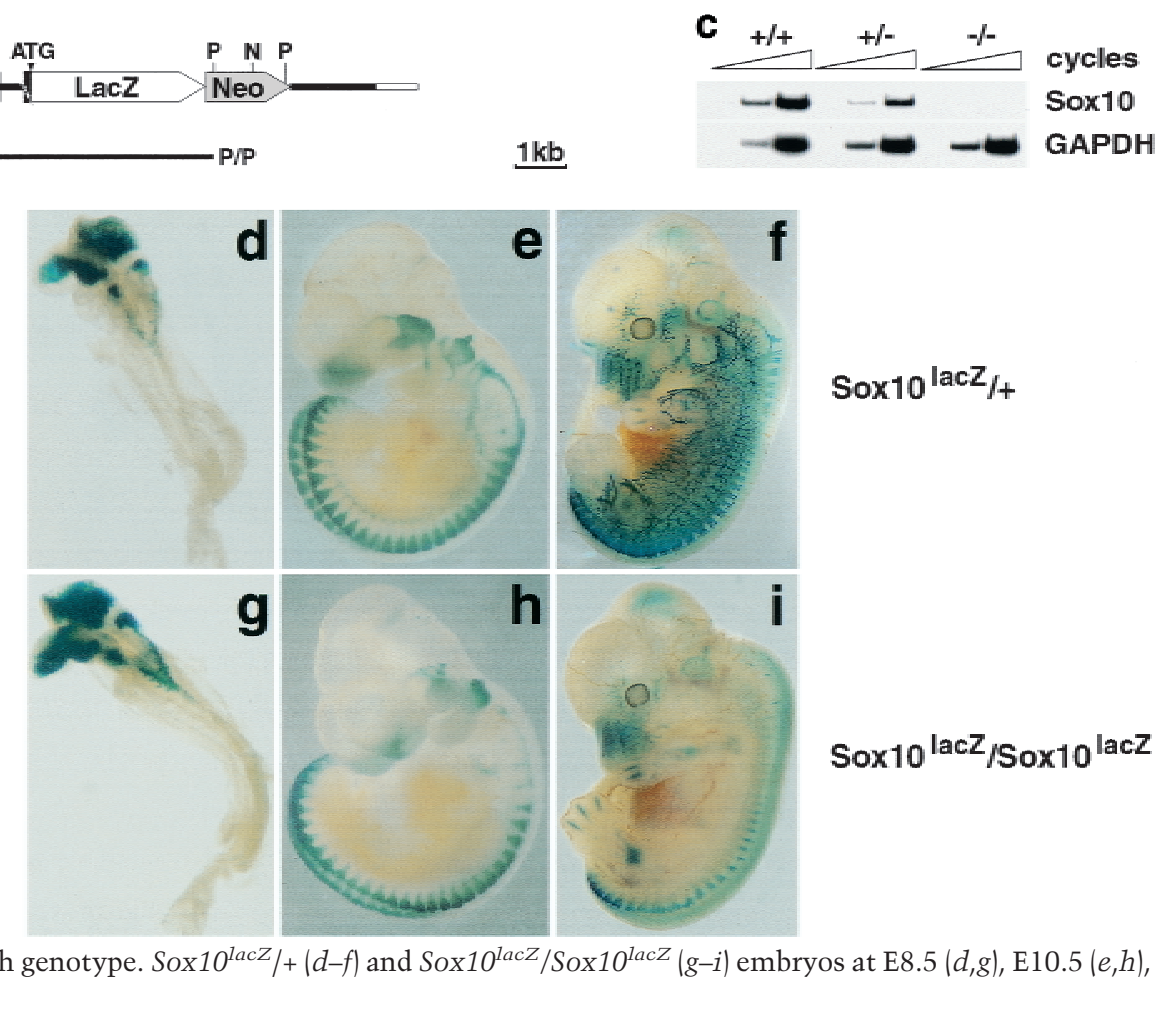
from 20, 23, and 26 cycles are shown for each genotype. Sox $10^{1 a c z} /+(d-f)$ and Sox $10^{1 a c z} /$ Sox $10^{1 a c z}(g-i)$ embryos at E8.5 $(d, g)$, E10.5 $(e, h)$, and E12.5 $(f, i)$ after X-gal staining.

16.5 of development (E16.5), but the ratio was lower at E18.5 (13.9\%, 72 animals examined). Sox $10^{\text {Iacz } /}$ Sox $10^{\text {Iac } Z}$ mice did not exhibit any gross morphological abnormalities at birth, their hearts did beat, but they were cyanotic, did not breathe, and their lung alveoli did not expand. Moreover, their forelimb posture was abnormal, and they did not move or react to tactile stimulation. A failure to breathe appears to cause the perinatal death of Sox $10^{\text {lacZ }} / \operatorname{Sox}_{10} 0^{\text {lacZ }}$ mice. Sox 10 expression was analyzed by semiquantitative RT-PCR (Fig. 1c), Northern blot analysis, and in situ hybridization (data not shown). As expected, we were unable to detect Sox10 transcripts in $\operatorname{Sox} 10^{\text {lacZ }} /$ Sox $10^{\text {lac } Z}$ mice. Compared with wild-type littermates, Sox10 mRNA levels were reduced by approximately half in the heterozygotes.

\section{Expression of $\beta$-galactosidase in Sox $10^{\text {lacz }}$ mice}

The lacZ sequence present in the Sox $10^{\text {Iac } Z}$ allele enables the visualization of its expression by $\beta$-galactosidase staining (Fig. 1d-f). At E8.5, $\beta$-galactosidase staining was detected in the cephalic fold and in neural crest cells emerging from the rostral neural tube (Fig. 1d). At E10.5, $\beta$-galactosidase staining was prominent in neural crest cells migrating to and in the gut, in sensory ganglia of the head and trunk, in the primary sympathetic ganglion chain, or in cells localized along the developing axon tracts. Staining was also observed in the otic and nasal placodes (Fig. 1e). At E12.5, $\beta$-galactosidase staining in Schwann cell precursors located along peripheral nerves was prominent. Staining was also detected in single cells located subcutaneously, that is, melanoblasts, and in oligodendrocyte precursors of the central nervous system (Fig. 1f; data not shown). These sites of lacZ expression are identical to those reported for Sox10 (Kuhlbrodt et al. 1998a; Pusch et al. 1998). Additional weak $\beta$-galactosidase staining was noted in mesenchymal condensations of the digits, radius, and ulna. Possibly, low levels of expression in these structures precluded their previous identification.

A comparison of $\beta$-galactosidase staining in heterozygous and homozygous $\operatorname{Sox} 10^{\text {lac } Z}$ mice revealed changes in the distribution of neural crest cells (Fig. 1d-i). At E8.5, generation and emigration of neural crest cells were unaltered (Fig. 1g). Differences in the distribution of $\beta$-galactosidase-positive cells became apparent at 
E10.5, that is, reduced numbers of stained cells in cranial ganglia and along their projections in Sox $10^{\text {lacZ/ }}$ Sox10 $0^{\text {lacZ }}$ embryos (Fig. 1, cf. h and e). $\beta$-Galactosidasepositive cells in the gut were absent and their numbers were reduced in the sympathetic primordium. At E12.5, differences were pronounced: In dorsal root ganglia, we noted a rostro-caudal gradient in the staining intensity in Sox $10^{\text {lacZ }} /$ Sox $10^{\text {lac } Z}$ mice not present in the heterozygous mice (Fig. 1i). Most conspicuous was the severe reduction of $\beta$-galactosidase-positive cells along peripheral nerves. In contrast, staining in the olfactory epithelium, the otic vesicles, and the central nervous system persisted, as did the staining associated with developing cartilage. Many of these changes in Sox $10^{\text {lacZ }} /$ Sox $10^{\text {lacZ }}$ mice reflect phenotypes described previously in Sox ${ }^{\text {Dom } /}$ Sox ${ }^{\text {Dom }}$ mice and, in general, we did not observe phenotypic differences in the two mutants (Herbarth et al. 1998; Southard-Smith et al. 1998; Kapur 1999).

\section{Sox10 controls expression of ErbB3}

Sox10 and ErbB3 are expressed in similar patterns in neural crest cells (Fig. 2a-d) and overlaps in phenotypes of Sox10 and ErbB3 mutants exist (see also below). We therefore tested whether the two genes interact genetically. When ErbB3 is used as a probe to detect neural crest cells in Sox $10^{D o m} / \operatorname{Sox} 10^{D o m}$ mice, expression is markedly down-regulated (Fig. 2f,h,j). Other genes expressed by neural crest cells, like $p 75^{N T R}$, Cadherin-6, or Sox10 are not down-regulated; note that Sox10 probes reveal the distribution of neural crest cells in Sox $10^{D o m} /$ Sox $10^{D o m}$, as a transcript is produced from the mutant allele (Fig. 2e-k; data not shown). The severe down-regulation of ErbB3 is pronounced at E10.5, but ErbB3-positive neural crest cells are present caudally, where neural crest cells are still generated (arrow in Fig. 2f). Similarly, on E9.0 a rostro-caudal gradient in down-regulation was noted in Sox $10^{\text {Dom }} /$ Sox $10^{\text {Dom }}$ mutants. Rostrally, ErbB3 expression was down-regulated, but caudally, neural crest cells that just emerged from the neural tube still express ErbB3 (arrows in Fig. 2j,1). Thus, ErbB3 expression is initiated in neural crest cells of Sox $10^{D o m} /$ Sox $10^{\text {Dom }}$ mutants, but later, when the cells have moved away from their origin, it is not maintained. ErbB3 is not only expressed in neural crest cells and their derivatives, but also in the myotome (arrowhead in Fig. 2d); the latter expression domain is not shared with Sox10 and myotome expression of ErbB3 is not affected in Sox $10^{D o m} /$ Sox $10^{\text {Dom }}$ mice (arrowheads in Fig. $2 \mathrm{f}, \mathrm{h}, \mathrm{j}$ ).

To test the effect of Sox10 on ErbB3 expression in vitro, Sox10 was expressed in N2A neuroblastoma cells in an inducible manner using the tet-on system, and transcript levels were measured by semiquantitative RT-PCR (Peirano et al. 2000). In the presence of doxycycline, Sox10 transcript levels increased, as did the levels of transcripts from the endogenous ErbB3 gene (Fig. 3a). This was confirmed by Northern blot analysis (Fig. $3 c)$. In contrast, expression of Sox 11 had no effect on ErbB3 mRNA levels, nor did the expression of a cDNA that encodes the Sox10fs variant derived from the Sox $10^{\text {Dom }}$ allele (Fig. 3a,b). Whether the effect of Sox10 on $\operatorname{ErbB} 3$ expression is direct is unclear. The kinetics of induction favor such a model, but reporter gene assays in transiently transfected N2A cells failed to identify a Sox10-responsive element in $40 \mathrm{~kb}$ of genomic ErbB3
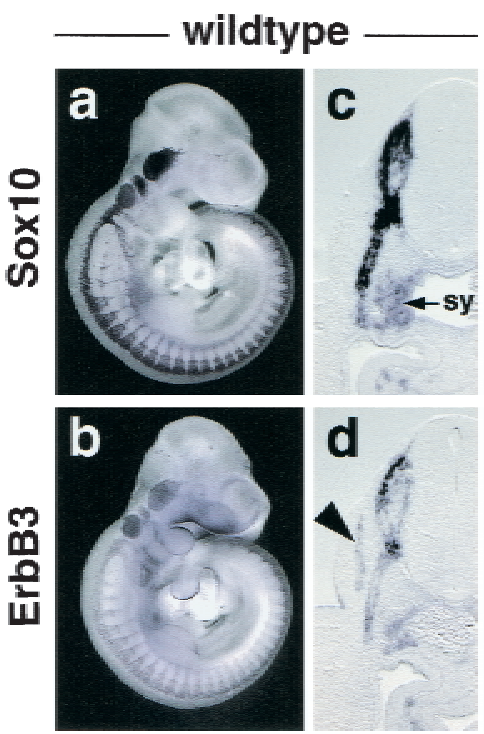

Sox $10^{\text {Dom }} /$ Sox $_{10} 0^{\text {Dom }}$
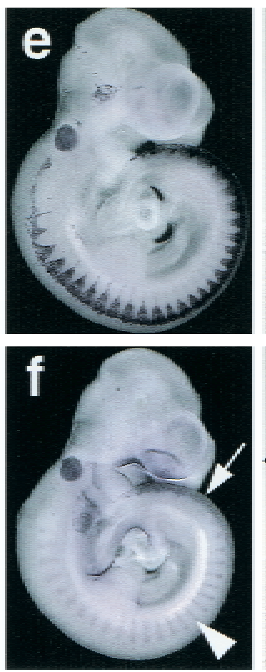
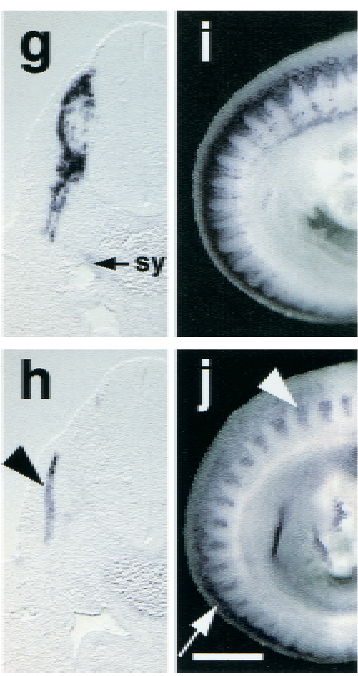

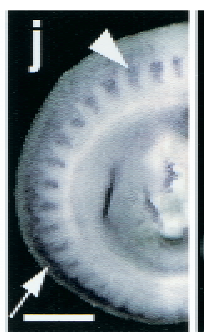

ErbB3-/-
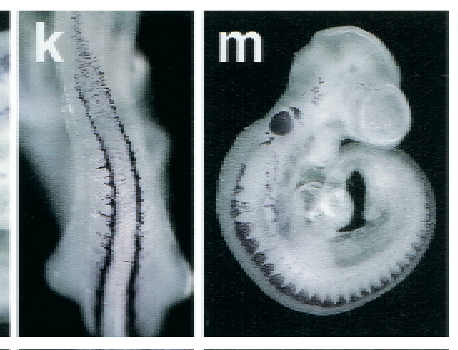

o
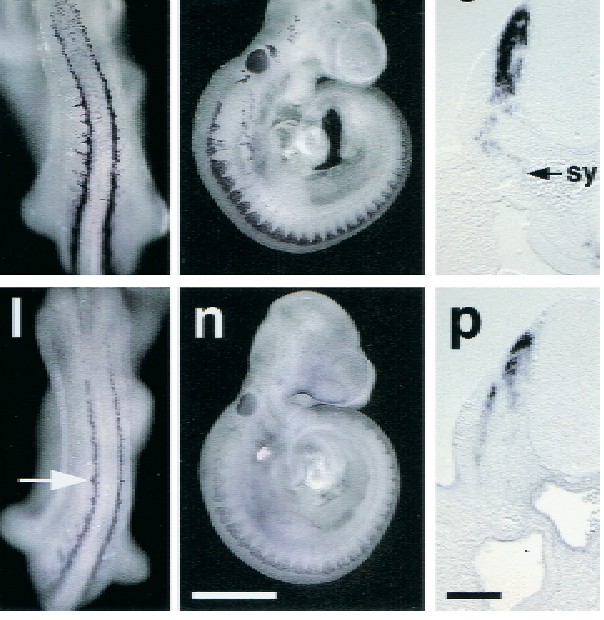

Figure 2. Sox10 controls expression of ErbB3. Whole-mount in situ hybridizations of wild-type $(a-d)$, Sox $10^{D o m} / \operatorname{Sox} 10^{D o m}(e-1)$, and ErbB3-/- $(m-p)$ embryos with probes specific for Sox10 (top), and ErbB3 (bottom). Shown are lateral $(a, b, e, f, m, n)$ views of E10.5 embryos and the corresponding vibratome sections $(c, d, g, h, o, p)$ on forelimb levels. Lateral $(i, j)$ and dorsal $(k, 1)$ views of Sox $10^{D o m} /$ Sox $10^{\text {Dom }}$ embryos at E9.0. Arrows in $f, i$, and 1 point toward ErbB3-expressing cells close to the neural tube in Sox $10^{D o m} /$ Sox $10^{D o m}$ embryos; arrows in $c, g$, and o point toward the anlage of the primary sympathetic ganglion chain (sy); arrowheads in $d, f, h$, and $j$ point toward the myotome that also expresses ErbB3. Bars $(a, b, e, f, m, n) 1 \mathrm{~mm} ;(c, d, g, h, o, p) 100 \mu \mathrm{m} ;(i-1) 300 \mu \mathrm{m}$. 


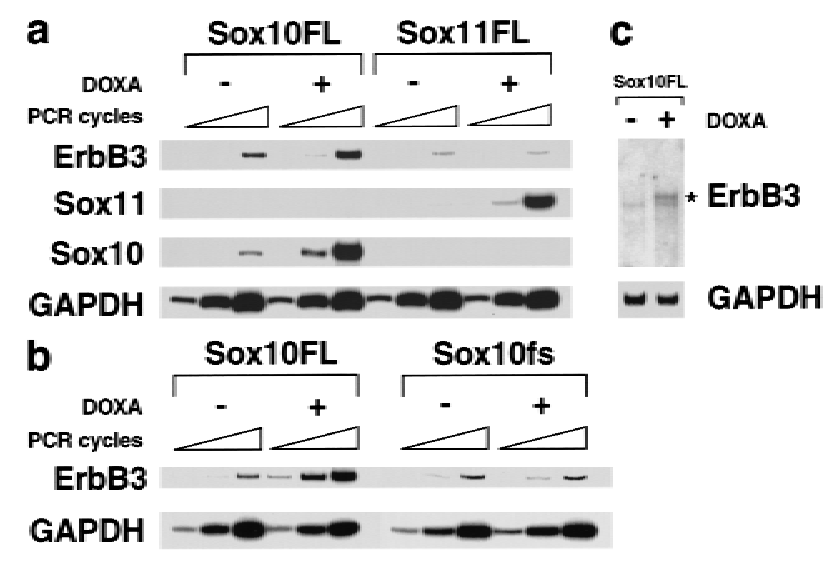

Figure 3. Sox10 increases endogenous ErbB3 expression in N2A cells. $(a, b)$ RT-PCR analysis of mRNA obtained from N2A cells that express Sox10, Sox11, or a mutant version of Sox10 (FL, wild-type cDNAs; Sox10fs, Sox $10^{D o m}$ mutant; Kuhlbrodt et al. 1998b) in an inducible manner. Doxycycline (DOXA) was used to induce the expression of the transcription factors $(+)$, which was compared to the uninduced state $(-)$. ErbB3 transcript levels were compared in the various transfectants by semiquantitative PCR, using increasing numbers of amplification cycles $(20,23$, and 26); in addition, the expression of GAPDH, Sox10, and Sox11 was monitored. (c) Northern blot analysis on $2 \mu \mathrm{g}$ of poly(A) ${ }^{+}$RNA from uninduced (left) and doxycycline-treated (right) N2A cells that express Sox10 in an inducible manner. The ErbB3-specific signal is indicated by an asterisk.

DNA (M. Wegner, R. Peirano, and D. Riethmacher, unpubl.).

\section{Common phenotypes in ErbB3 and Sox10 mutant mice}

If Sox10 is essential for correct expression of ErbB3, phenotypes of ErbB3 mutant mice should be present in Sox10 mutants, which is indeed the case. Cranial ganglia and their projections can be visualized in control mice by in situ hybridization using a Sox10 probe, but only remnants are present in $\mathrm{ErbB3}^{-/-}$and Sox10 mutant mice (Fig. 2a,e,m). Also, the morphology of cranial ganglia in both mutants is changed in a similar manner when analyzed by histology or with antineurofilament antibodies (Meyer and Birchmeier 1995; Erickson et al. 1997; Meyer et al. 1997; Riethmacher et al. 1997; Herbarth et al. 1998). This reflects the absence of those portions of cranial ganglia that derive from neural crest cells. Furthermore, Sox10-positive cells are abundant along the axon tracts in control embryos at E10.5 and are significantly reduced in numbers in ErbB3 and Sox10 mutants (Fig. 2, cf. e,g and $\mathrm{m}, \mathrm{o}$ to control in a,c). This phenotype appears somewhat less severe in Sox10 than in ErbB3 mutants, which we attribute to the transient expression of ErbB3 in neural crest cells of Sox10 mutants. Finally, the sympathetic primordium is severely hypoplastic in ErbB3 and Sox10 mutants, and a rostro-caudal gradient in the severity is apparent (arrows in Fig. 2c, g, O; cf. Britsch et al. 1998; Kapur 1999). Thus, various early deficits in neural crest cells and their derivatives present in ErbB3 mutants are also found in Sox10 mutants. However, additional phenotypes exist in the Sox10 mutants, for instance, the absence of enteric neural crest cells, that are not observed in $\mathrm{ErbB}^{-/-}$mice.

\section{Sox10 is essential for differentiation of peripheral glia}

Many genes expressed by neural crest cells are turned off in differentiated neurons but remain expressed in developing glial cells. Genes that display such expression patterns include Sox10, ErbB3, and Cadherin-6. However, markers that distinguish neural crest cells from newly formed glia are scarce. Brain-specific fatty acid binding protein (B-FABP; Kurtz et al. 1994) is nondetectable in neural crest cells but is easily detected in various peripheral glial populations. For example, whereas no B-FABPpositive cells along spinal nerves or in dorsal root ganglia are found at E10.5 in mice on lumbar axial levels by immunohistochemistry, they are abundant at E11.5 (Fig. $4 \mathrm{a}, \mathrm{b}$; data not shown). In sympathetic ganglia, B-FABPpositive cells appear on E12.5. Nonoverlapping cell populations stain with B-FABP- and neuron-specific antibodies, respectively. Several days later, the S100-antigen appears in glial cells and is coexpressed with B-FABP, for instance, in satellite cells of dorsal root ganglia or in Schwann cells (not shown). B-FABP distinguishes glia from neural crest cells and neurons during early stages of development of the peripheral nervous system.

Sensory neurons in dorsal root ganglia form on a similar temporal schedule in control, Sox10, and ErbB3 mutant mice, as analyzed by the use of TuJ-1 antibodies (Fig. $4 \mathrm{~b}, \mathrm{~d}, \mathrm{f}_{;}$data not shown). In control mice at E11.5, B-FABP-positive cells are abundant in dorsal root ganglia and along spinal nerves on lumbar axial levels (Fig. 4a,b). In homozygous Sox10 mutants, B-FABP-positive cells are detected neither in the dorsal root ganglia nor along the spinal nerves (Fig. 4c,d). This does not reflect simply a delay of glial differentiation, as B-FABP-positive cells are also absent at E12.5 (Fig. 5h). In contrast, in ErbB3 mutants B-FABP-positive cells are abundant in the ganglia but are very rare along the nerves (Fig. 4e,f). Thus, in ErbB3 mutant mice, glial cells can be formed, but the numbers of such cells that line nerves are strongly reduced, reflecting the reduced numbers of neural crest cells along axons at E10.5. In the superior cervical ganglion, B-FABP-positive cells arise at E12.5 in control mice. In Sox10 and ErbB3 mutant mice, this most anterior sympathetic ganglion is small. B-FABP-positive satellite cells can be detected in ErbB3 but not in Sox10 mutants. Satellite cells were also absent in the nodose ganglion of Sox10 mutants but not of ErbB3- ${ }^{-/-}$mice (not shown).

Sox10 is among those genes that are expressed in neural crest cells as well as in glia. In control embryos at E11.5, Sox10-positive cells are abundant in dorsal root ganglia and line the spinal nerves in great numbers (Fig. $4 \mathrm{~g})$. In Sox $10^{D o m} /$ Sox $10^{D o m}$ mutants at E11.5, reduced numbers of cells that express the mutant Sox10 gene are 


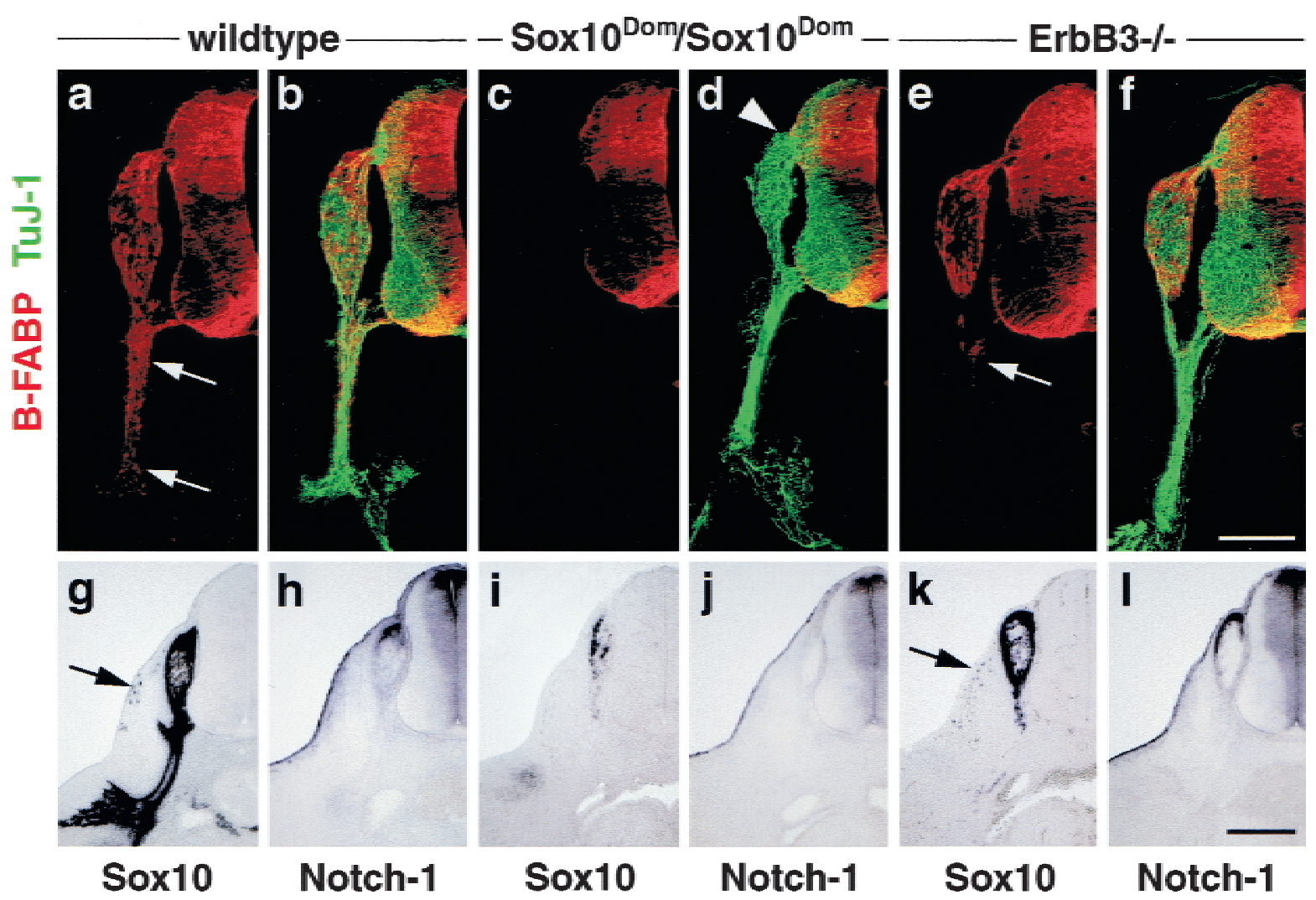

Figure 4. Sox10 controls peripheral glial cell development. $(a-f)$ Immunohistological analysis of wild-type $(a, b)$, Sox $10^{\text {Dom }} /$ Sox $10^{D o m}$ $(c, d)$, and $E_{r b B 3^{-I}}(e, f)$ embryos at E11.5 on lumbar axial levels, using antibodies against B-FABP (red) and TuJ-1(green) to visualize peripheral glial cells and neuronal cells, respectively. B-FABP antibody signals $(a, c, e)$ and an overlay of B-FABP and TuJ-1 antibody signals $(b, d, f)$ are shown. The arrowhead in $d$ points towards the abnormally shaped dorsal root entry zones in Sox $10^{D o m} /$ Sox $10^{D o m}$ mutants; the arrows point towards B-FABP-positive Schwann cell precursors that line spinal nerves in control and ErbB3 ${ }^{-1-}$ mice. $(g-1)$ In situ hybridization of wild-type $(g, h)$, Sox10 Dom $/ \operatorname{Sox} 10^{D o m}(i, j)$, and ErbB3-l- $(k, 1)$ embryos at E11.5 with probes specific for Sox10 $(g, i, k)$ or Notch-1 $(h, j, 1)$. Sections on lumbar axial levels are shown. Bars $(a-f) 100 \mu \mathrm{m} ;(g-1) 150 \mu \mathrm{m}$.

present in dorsal root ganglia and along the spinal nerves (Fig. 4i). Because differentiated glial cells that express B-FABP are not present, the few remaining Sox10-positive cells appear to correspond to undifferentiated neural crest cells. In ErbB3 ${ }^{-/-}$mutants at E11.5, Sox10-positive cells are abundant in the ganglia but severely reduced along the spinal nerves, reflecting the distribution of BFABP-positive cells (Fig. 4k). Notch-1 is transiently expressed during early stages of glial differentiation; Notch-1 signal controls the expression of Hes-5 (Weinmaster et al. 1991; Kageyama and Nakanishi 1997). Notch-1 or Hes-5 transcripts are not detectable in dorsal root ganglia of Sox $10^{D o m} / \operatorname{Sox} 10^{D o m}$ mice but are present in ErbB3 mutants and control embryos (Fig. 4h,j,l; data not shown). Histological analysis shows that peripheral nerves lack Schwann cell nuclei in Sox10 mutant mice at E12.5 (Fig. 5, cf. j and control in e). These nerves contain essentially only naked axons and are smaller in diameter than in control mice.

Immunohistochemistry was used to determine the differentiation status and the fate of $\beta$-galactosidase expressing cells in Sox10 1 lacZ mice. In heterozygous embryos at E11.5, B-FABP and $\beta$-galactosidase staining did overlap to a large extent, but colocalization of $\beta$-galactosidase and Islet-1 or peripherin was not observed (Fig. $5 \mathrm{a}, \mathrm{b}$; data not shown). In Sox $10^{1 a c Z} / \operatorname{Sox} 10^{\text {lacZ }}$ mice, residual $\beta$-galactosidase-positive cells, which express neither B-FABP nor neuronal markers like peripherin, were present. Thus, despite their inability to differentiate into glial cells, the remaining $\beta$-galactosidase-positive cells had not adopted a neuronal fate in the Sox $10^{\text {lacZ/ }}$ Sox $10^{\text {lac } Z}$ mice. The further destiny of these cells was not followed, as an extensive and general apoptosis in dorsal root ganglia sets in at E11.5 in these mutants (see also below).

Degeneration of sensory and motoneurons in Sox10 and ErbB3 mutant mice

Dorsal root ganglia form in Sox10 and ErbB3 mutant mice and are of similar size as those of control embryos at E10.5 (Fig. 2a,c,e,g,m,o). However, the dorsal root ganglia form broad fusions with the lateral neural tube, which contain, inappropriately, neurons in Sox10 mutants (arrowheads in Figs. 4d and 5h,i). Neuronal peri- 


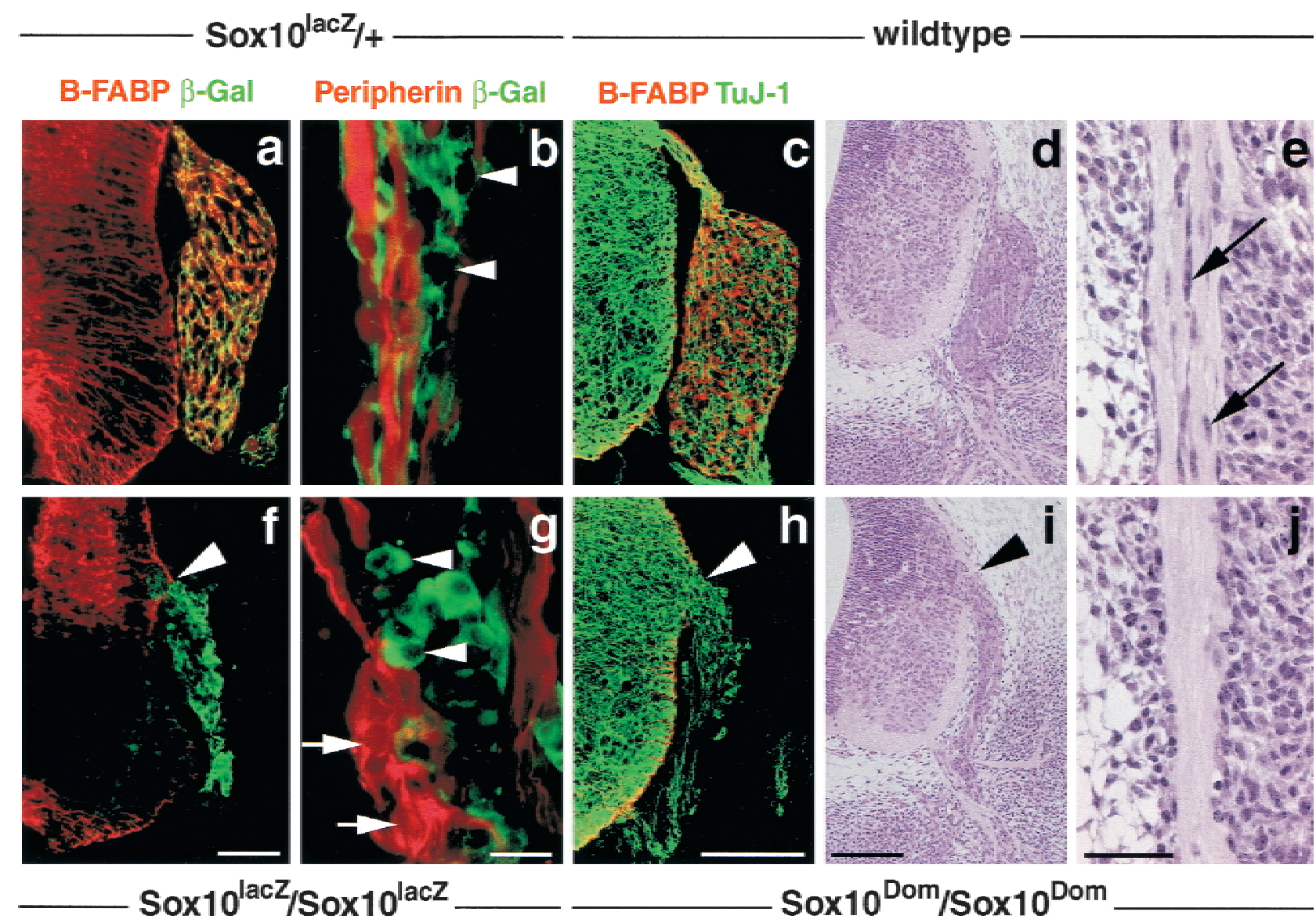

Figure 5. Appearance of dorsal root ganglia in homozygous Sox10 mutant animals. Histological and immunohistological analyses of dorsal root ganglia and spinal nerves in Sox $10^{1 a c Z} /+(a, b)$, wild-type $(c-e)$, Sox $10^{\text {IacZ }} /$ Sox $10^{1 a c Z}(f, g)$, and Sox $10^{D o m} /$ Sox $10^{D o m}(h-j)$ animals at E11.5 $(a, b, f, g)$ and E12.5 $(c-e, h-j)$. $(a, f)$ Immunohistological analysis using antibodies against B-FABP (red) and $\beta$-galactosidase (green). Note that B-FABP and $\beta$-galactosidase from the Sox10-lacZ reporter are coexpressed (yellow) in satellite glia of dorsal root ganglia of control mice. B-FABP is not expressed in $\operatorname{Sox} 10^{1 a c Z} /$ Sox $10^{\text {lac } Z}$ mice, although $\beta$-galactosidase-positive cells persist. (b, $g$ ). High-magnification of ventral roots stained with antibodies against peripherin (red) and $\beta$-galactosidase (green). Arrowheads point towards cells that express $\beta$-galactosidase; arrows point towards neuronal cells expressing peripherin. Note that the two proteins are coexpressed in neither control nor homozygous mutant mice, indicating that the $\beta$-galactosidase-positive precursor cells have not adopted a neuronal fate in Sox $10^{1 a c Z} / \operatorname{Sox} 10^{1 a c Z}$ mice. $(c, h)$ Immunohistological analysis with antibodies against TuJ-1 (green) and B-FABP (red), which visualize neuronal and glial cells, respectively. Histological appearance of dorsal root ganglia $(d, i)$ and intercostal nerves $(e, j)$ at E12.5. Note the marked reduction in size of the ganglion in the mutant mice. In control mice, nuclei associated with the intercostal nerve are abundant (arrows in $e$ ), which are not observed in the Sox10 mutant. Note also the abnormal dorsal root entry zones in homozygous mutants, which are indicated by arrowheads in $f, h$, and $i$. Bars $(a, f) 80 \mu m_{;}(b, g) 15 \mu m_{;}(c, d, h, i) 150 \mu \mathrm{m} ;(e, j)$ $50 \mu \mathrm{m}$.

karya were also detected in the ventral roots of spinal nerves of Sox10 mutants (Fig. $5 \mathrm{~g}$ ). These changes were not present in $\mathrm{ErbB3}^{-/-}$mice. Even more conspicuous is the severe degeneration of neurons in dorsal root ganglia of Sox10 mice, which is already detectable at E11.5 on lumbar axial levels and has affected a major proportion of the neurons at E12.5 (Fig. 5h,i). Degeneration of sensory neurons was also observed previously in $\mathrm{ErbB3}^{-/-}$mice, but first sets in around E12.5 on lumbar axial levels (Riethmacher et al. 1997; Woldeyesus et al. 1999). Not only is the onset of degeneration of sensory neurons earlier in Sox10 mutants, but it is also more severe. At E18.5, very few cells are detectable in the remnants of lumbar dorsal root ganglia of Sox10 mutants, whereas at this stage about $20 \%$ of the sensory neurons can still be found in dorsal root ganglia of $\mathrm{ErbB3}^{-/-}$mutants (cf. Riethmacher et al. 1997; Woldeyesus et al. 1999).

Motoneurons are generated in Sox10 mutants, but they subsequently degenerate. Motoneuron degeneration was also reported previously in $E r b B 3^{-/-}$mice (Riethmacher et al. 1997; Woldeyesus et al. 1999). We compared the numbers of motoneurons on different axial levels in

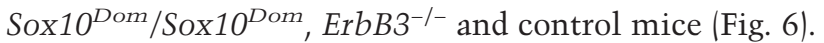
Compared with control mice at E15.5, numbers of motoneurons are somewhat reduced in Sox10 and ErbB3 mutant mice on cervical, but not on thoracic or lumbar, axial levels (Fig. 6c). At E18.5, a very significant loss of motoneurons is observed on cervical and lumbar axial 


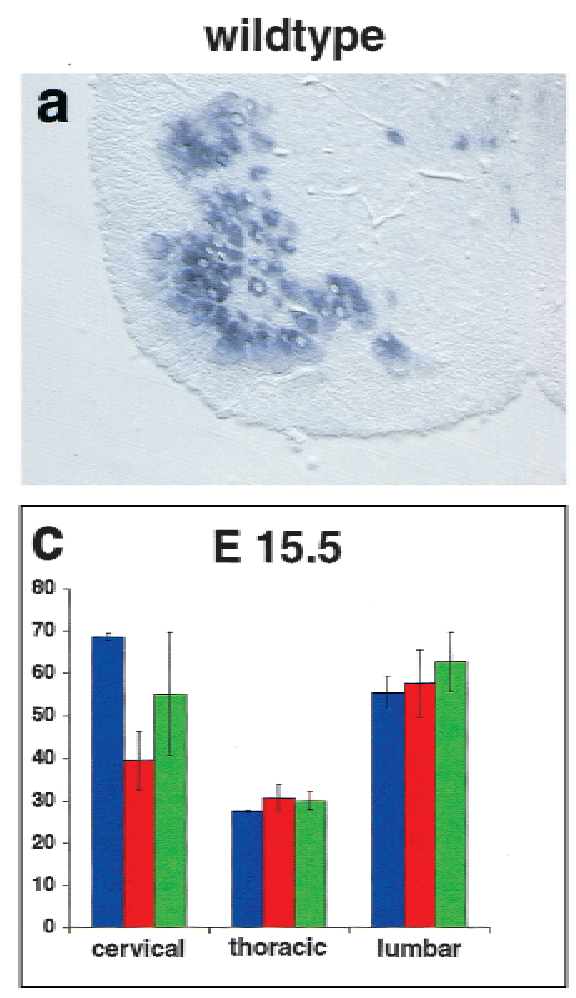

wildtype
Sox $10^{\text {Dom }} /$ Sox $10^{\text {Dom }}$
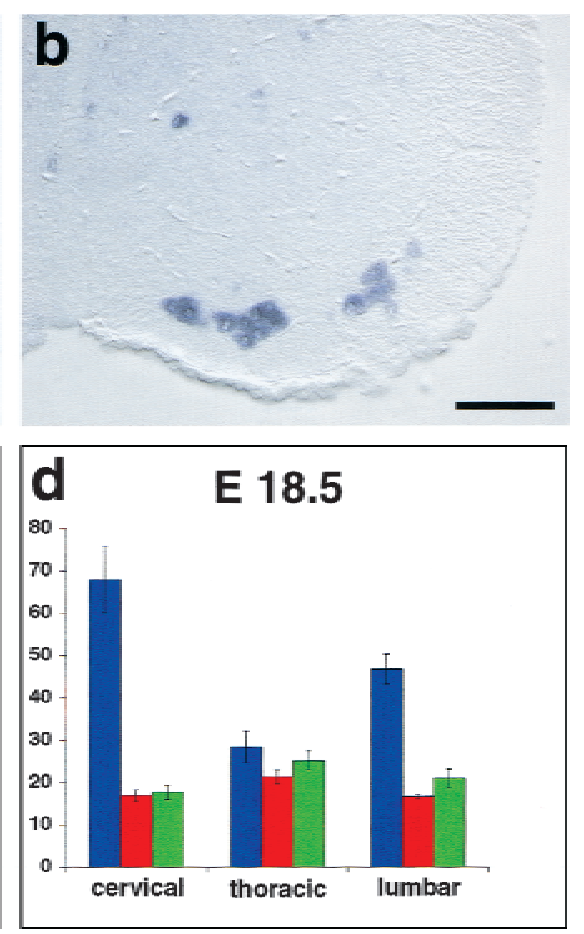

Figure 6. Loss of motoneurons in Sox $10^{D o m} /$ Sox $10^{D o m}$ and ErbB3 $3^{-/-}$mutant mice. Sections of the cervical spinal cord of wild-type $(a)$ and Sox $10^{D o m} / \operatorname{Sox} 10^{D o m}$ (b) mutant animals at E18.5 after in situ hybridization with a VAChT specific probe. $(c, d)$ Motoneuron numbers in cervical, thoracic, and lumbar segments of spinal cords obtained from wild-type (blue columns), Sox $10^{\text {Dom }} /$ Sox $10^{\text {Dom }}$ (red columns), and $\mathrm{ErbB3}^{-/-}$(green columns) mutants at E15.5 (c) and E18.5 (d). Mean numbers of motoneurons per section +/- S.D. are shown $(n=4$ embryos for each genotype and developmental stage). Counts were not corrected for neuron size, and the numbers of neurons at different developmental stages are therefore not strictly comparable. Bar $(a, b) 100 \mu \mathrm{m}$. levels in ErbB3 and Sox10 mutants, and the extent of the motoneuron loss is identical. Motoneurons in thoracic segments are little affected (Fig. 6d).

\section{Melanocyte development in Sox10 mutant mice}

Melanocytes develop from neural crest cells that are generated late and migrate on the dorso-lateral pathway below the skin. These migrating cells begin to express genes typical for the melanocyte lineage, like c-kit, trp-2, or $\mathrm{mi}$ after they have moved a short distance from the neural tube. Sox10 continues to be expressed in migrating melanocytes (arrow in Fig. 4g). In Sox10 mutants, these cells are reduced in numbers (Figs. $4 i$ and 7). Similarly, numbers of subcutaneous $\beta$-galactosidase-positive cells in $\operatorname{Sox} 10^{\text {lacZ }} / \operatorname{Sox} 10^{1 a c Z}$ mice are severely reduced (not shown).

Differentiation of melanocytes was analyzed in Sox10 mutant mice, using markers for the early melanocyte lineage. The receptor tyrosine kinase c-kit and its specific ligand steel/stem cell factor play important roles in survival and migration of melanocytes /Geissler et al. 1988; Huang et al. 1990). In wild-type embryos, a stream of c-kit-positive melanocytes can be detected along the dorso-lateral pathway at E12.5 (Fig. 7a). We determined the number of such subcutaneous cells, using sections on the hindlimb level of E12.5 mice of different genotypes. Compared with wild-type mice, the numbers of c-kit-positive cells were reduced by half in mice with a heterozygous mutation in Sox10 (Fig. 7c,g). In homozygous mice, the reduction was more pronounced. Mutants contained only $24 \%$ of the cells compared with wildtype embryos (Fig. 7e,g).

Melanocyte development requires also the bHLH transcription factor mi that is encoded by the microphthalmia locus (for recent review, see Goding 2000). In wildtype mice at E12.5, the number of mi-positive cells was comparable to the number of c-kit-positive cells (Fig. 7c). In mice heterozygous for the Sox10 mutation, mi-positive cells were reduced by half (Fig. 7c,g). We were unable to detect any mi-positive cells in homozygous Sox10 mutant embryos (Fig. 7e,g). The tyrosinase-related protein 2 (trp-2) is encoded by the slaty locus and is expressed early in development of the melanocytic lineage (Jackson et al. 1992). The number of trp-2-positive cells in wild-type embryos at E12.5 was comparable to the number of c-kit- or mi-positive cells, consistent with the three markers labeling the same population of cells in the skin at this stage. In heterozygous mice, we detected only $12 \%$ of the trp-2-positive cells counted in wild-type mice (Fig. $7 \mathrm{~d}, \mathrm{~g}$ ). Thus, the reduction in numbers of trp2-positive cells is more pronounced than the reduction in mi- or c-kit-positive cells. Moreover, those trp-2-positive cells present in heterozygous mice appeared to stain less intensely. In homozygous Sox10 mutants, trp-2 expressing cells were not detected (Fig. $7 \mathrm{f}, \mathrm{g}$ ). The absence of trp-2-positive cells in homozygous Sox10 mutants also was apparent in other regions of the embryo and at E11.5 (not shown). Thus, a quantification of melanoblast numbers demonstrates that a severe and early loss of melanoblasts occurs in Sox10 mutant mice. In contrast, development of melanocytes in the retinal pigment epithelium was not affected. 
Britsch et al.

Figure 7. Sox10 controls development of melanoblasts and expression of the trp-2 gene. $(a-f)$ Transverse sections of wildtype $(a, b)$, heterozygous $(c, d)$, and homozygous $(e, f) \operatorname{Sox} 10^{1 a c Z}$ mice at E12.5 on corresponding hindlimb levels. Embryos were hybridized with probes specific for c-kit (a,c,e; main panels), mi (a,c,e; insets), and trp-2 $(b, d, f)$. (g) Melanoblasts positive for c-kit, mi, or trp-2 in wild-type $(+/+$, black $)$, heterozygous $(+\mid-$, gray), and homozygous (-/-, white) Sox10-deficient mice at E12.5. The numbers of positive cells in wild-type mice identified by each marker were arbitrarily set to $100 \%$. (h) Luciferase reporter assay determining the interaction of Sox 10 and the trp-2 gene. Reporter genes were transfected into tet-on N2A cells. Luciferase was expressed under the control of the 3.7-kb trp-2 promoter (trp2luc), the $\mathrm{P}_{\mathrm{O}}$ promoter (POluc), or the thymidine kinase promoter (TKluc) or were lacking a specific promoter (pGL2). Luciferase activity was measured before and after doxycycline treatment. Sox10-dependent promoter activation was expressed as the ratio between these two values. Bars represent the result from three independent transfections +/- S.E.M.
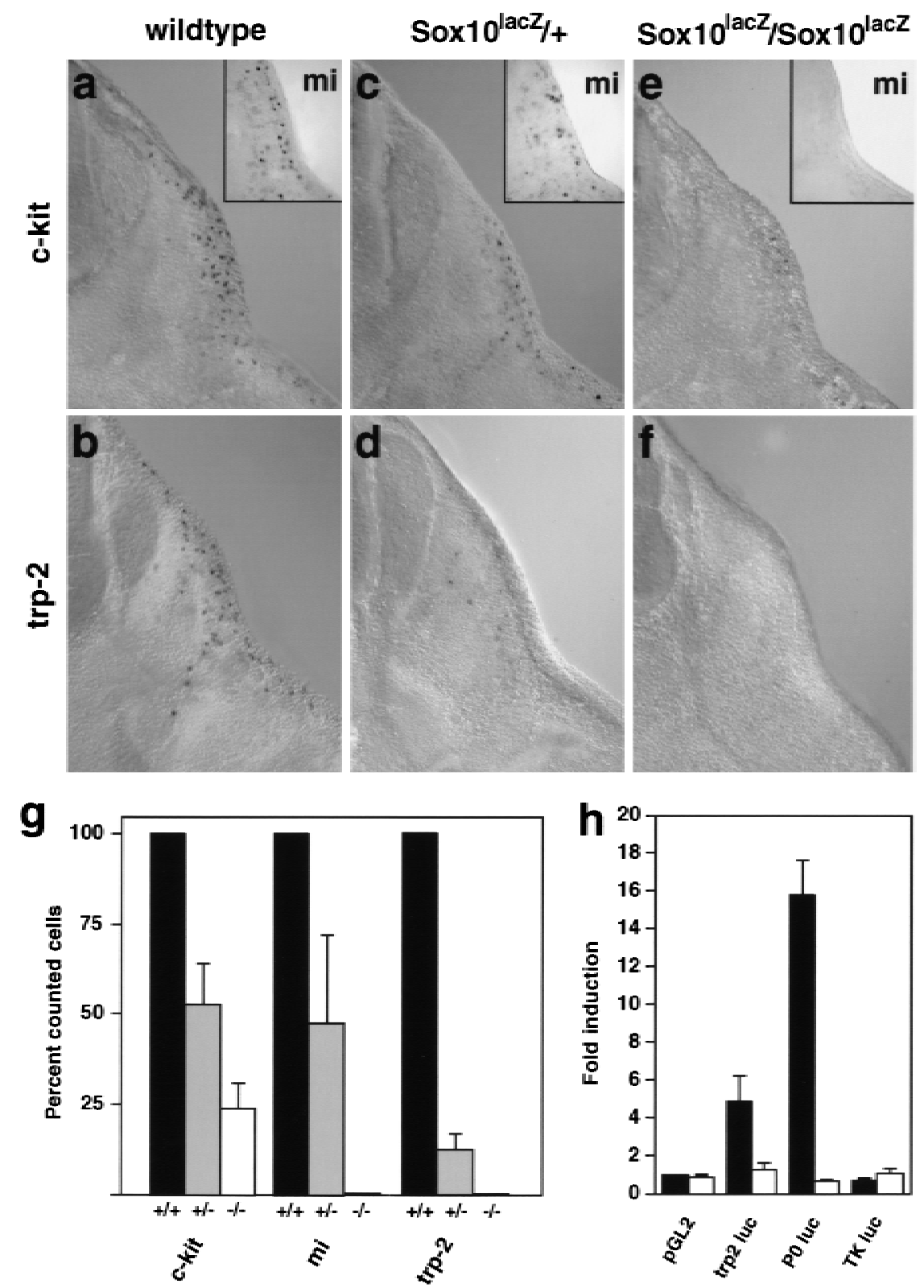

Trp-2 is a direct target gene regulated by Sox10

The effect of the heterozygous Sox10 mutation on trp-2 expression levels prompted us to investigate whether a direct regulator-target gene relationship exists between Sox10 and trp-2. We analyzed expression of a luciferase reporter gene controlled by the mouse trp- 2 promoter, using a $3.7-\mathrm{kb}$ trp- 2 fragment $(-3290$ to +443 relative to the transcriptional start site) that suffices to drive transgene expression in melanocytes (Budd and Jackson 1995). This reporter was transiently transfected into N2A cells that express Sox10 in a doxycycline-dependent manner. We observed a fivefold activation of the trp-2 promoter in the presence of Sox10 (Fig. 7h). In parallel transfections, the $\mathrm{P}_{0}$ promoter was stimulated 16-fold. Sox10-dependent activation of the trp-2 promoter was specific, as the thymidine kinase promoter was not ac- tivated upon Sox10 induction; moreover, no increase in trp-2 promoter activity was observed in control N2A cells treated with doxycycline (Fig. 7h).

\section{Discussion}

Spontaneous mutations of the Sox10 gene were identified in mice and man that, in a heterozygous state, can affect pigmentation and the development of enteric ganglia. These spontaneous mutant alleles can encode truncated proteins, which might act in a dominant-negative manner (Kuhlbrodt et al. 1998b; Pingault et al. 1998; Southard-Smith et al. 1999). We generated a novel, targeted allele of the mouse Sox10 gene that deletes the entire reading frame. The analysis of these $\operatorname{Sox} 10^{1 a c Z} \mathrm{mu}-$ tant mice demonstrates that haploinsufficiency can ex- 
plain the pigmentation and megacolon phenotypes observed in heterozygous Sox $10^{D o m}$ mice and in patients with Waardenburg-Hirschsprung disease. Thus, although spontaneous mutations might have also dominant-negative effects, such mechanisms are not necessary for the manifestation of an overt phenotype. The expressivity of pigmentation defects in heterozygous Sox ${ }^{l a c Z}$ mice depends on the genetic background, as found previously in Sox $10^{D o m}$ mutants. Modifier loci affect thus the penetrance of certain phenotypes caused by haploinsufficiency.

\section{Sox10, ErbB3, and glial development}

In homozygous Sox10 mutant mice, the entire peripheral nervous system is defective and, in addition, particular motoneurons are absent. Our analysis reveals that two distinct mechanisms cause these changes. Early phenotypes arise during the development of neural crest cells and are in contrast to the late phenotypes, the degeneration of already formed ganglia or nerves. Sox 10 controls, among other genes, the expression of ErbB3, which encodes a Neuregulin receptor (Adlkofer and Lai 2000; Garratt et al. 2000). In the absence of ErbB3-mediated signals, migration and survival of particular neural crest cell types are impaired, which account for many early phenotypes in Sox10 mutants. The degeneration of neurons in Sox10 mutant mice can be attributed to the lack of glial cells.

The lack of glial cells in Sox10 mutants is caused by a differentiation defect. Differentiated glial cells were absent in those portions of the peripheral nervous system that form initially in Sox10 mutants. Schwann cell precursors along the projections of sensory and motoneurons did not form, nor did we detect satellite cells in sensory ganglia or in the superior cervical ganglion of the sympathetic nervous system. It is of interest to note that Sox10 was reported previously also to control directly expression of the myelin-associated gene $P_{O}$ (Peirano et al. 2000). A key role of Sox10 in the development of peripheral glial cells and in the control of genes that determine glial cell identity is thus emerging. It is of interest to note recent reports on some patients with Sox10 mutations, who display neurological symptoms reminiscent of Charcot-Marie-Tooth disease type 1, a disease typically associated with Schwann cell deficits (Inoue et al. 1999; Pingault et al. 2000; Touraine et al. 2000).

Homozygous Sox10 and ErbB3 mutant mice both display severe deficits in glial development, but the extent of these differs. The entire peripheral glial cell population, that is, Schwann cells and satellite cells, is missing in Sox10 mutants. In contrast, in ErbB3 mutants only the Schwann cell lineage is affected; precursors are reduced at early stages, and later, Schwann cells are absent. The underlying mechanisms that cause these changes also differ. In Sox10 mutants, the differentiation of peripheral glial cells is arrested in general at a very early stage. In contrast, the ErbB3/ErbB2 receptors and their ligand Neuregulin-1 control migration of Schwann cell precursors along axon tracts as well as survival and proliferation of such precursors (Adlkofer and Lai 2000; Garratt et al. 2000). We carefully assessed the presence of neural crest cells in dorsal root ganglia and along the spinal nerves before the onset of glial differentiation in Sox 10 mutants, using Sox10, $\beta$-galactosidase encoded by the Sox $10^{\text {lac } Z}$ allele, or $\mathrm{p} 75^{\mathrm{NTR}}$ as markers. At E10.5, a day prior to glial differentiation, neural crest cells are still abundant in the dorsal root ganglia, and the ganglia appear normal in size. Thus, initially, the mutation does not interfere with the maintenance of neural crest cells in the newly formed ganglia. At other sites, for instance along the spinal nerves, a severe reduction in numbers of neural crest cells is notable in Sox10 mutants. A mere reduction in precursor numbers along the spinal nerves does however not interfere with glial differentiation: In ErbB3 mutant mice, numbers are reduced, but the few remaining cells can nevertheless differentiate.

What is the fate of undifferentiated neural crest cells that do not generate glia in Sox10 mutants? In vivo, we have not obtained evidence that these cells form neurons or other, non-glial cell types that derive from the neural crest. Our data indicate that the precursors arrest their differentiation and are then eliminated by cell death. A more detailed analysis of this is hampered by the general cell death in the dorsal root ganglia of Sox10 mutants, which sets in around the time the first differentiated glial cells are observed in control mice. This apoptosis is not restricted to neural crest cells but also affects neurons.

It should be noted that Sox10 is expressed broadly in neural crest cells. However, only a subpopulation of these cells will take a glial cell fate and maintain Sox10 expression. Expression of Sox10 does not therefore suffice to generate glia, and additional signals are required. The function of Sox10 might be modified in cells that will form glia, for instance by a phosphorylation event controlled by signals that induce glial differentiation. Alternatively, Sox10 might cooperate with additional factor(s) regulated by such signals. The transcription factors Pax3, Krox20, and SCIP/Tst-1/Oct6 cooperate with Sox10, but mutations of mouse Pax3, Krox20 or SCIP/ Tst-1/Oct6 do not appear to affect the differentiation of neural crest cells into glia (Epstein et al. 1991; Franz and Kothary 1993; Topilko et al. 1994; Jaegle et al. 1996; Kuhlbrodt et al. 1998a). Our finding that Sox10 is essential for differentiation of neural crest cells into glia might suggest an experimental basis for the future elucidation of molecular mechanism(s) that specify the peripheral glial lineage. It is noteworthy that a transient Notch activation accelerates glial differentiation and suffices to suppress a neurogenic fate in cultured neural crest cells (Morrison et al. 2000; Wakamatsu et al. 2000). Notch-1 is expressed at low levels in neural crest cells and is transiently up-regulated during early glial development. Interestingly, Notch-1 expression is not detected in sensory ganglia of Sox10 mutant mice, as is the expression of Hes-5, which is controlled by Notch signals. The effect on Notch-1 expression might cause or contribute to the general deficit in glial differentiation. 
Degeneration of sensory, sympathetic, and motor neurons in Sox10 mutant mice

In Sox10 mutant mice, motoneurons form, but degenerate subsequently. The degeneration of motoneurons displays distinct kinetics and affects particular subclasses of motoneurons. Indirect effects account for the motoneuron death in Sox10 mutants, as at no time in development did we detect Sox10 transcripts in motoneurons or their precursors. In ErbB3 mutant mice, motoneurons also degenerate. Degeneration is identical in extent, kinetics, and affected axial levels in ErbB3 and Sox10 mutant mice. It is noteworthy that Sox10 is not expressed in muscle, and ErbB3 expression in muscle is not changed in Sox10 mutants. The common feature of the two mutants is the severe deficit in development of Schwann cells that accompany motor nerves. The comparison of the Sox10 and ErbB3 mutants demonstrates, unambiguously, that motoneuron degeneration is caused by a lack of Schwann cells and that Schwann cells have an essential role in the maintenance of distinct motoneuron subclasses.

Sensory neurons in dorsal root ganglia form and subsequently degenerate in Sox10 mutants. Also, the superior cervical ganglion is formed, albeit at reduced size, and it degenerates. We propose that the absence of peripheral glial cells causes the degeneration of sensory and sympathetic neurons in Sox10 mutants, and that both glial cell types, satellite cells as well as Schwann cells, provide essential trophic support. In ErbB3 mutants, sensory neurons also degenerate, but the degeneration is less pronounced and sets in later than in Sox10 mutants. Sat-

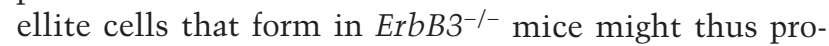
vide trophic support, which allows a partial rescue of the sensory neurons.

\section{The role of Sox10 in melanocyte development}

A late-emerging population of neural crest cells, which migrate along a dorso-lateral path below the skin, generate melanoblasts, the nonpigmented precursor cells of melanocytes. These cells start to express genes typical for the melanocyte lineage, like c-kit, mi, and trp-2, after they have moved a short distance away from the neural tube. Sox10 is expressed in the migrating melanoblasts. The development of the melanocyte lineage depends on Sox10, and, moreover, is even dosage dependent. A significant reduction in melanoblast numbers was noted in the heterozygous Sox $10^{1 a c Z}$ mice, accounting for pigmentation defects present in these animals. Analysis of this phenotype on a $\mathrm{C} 3 \mathrm{H}$ background may have augmented the effect, as this genetic background accentuates the melanocyte defect in heterozygous Sox $10^{D o m}$ mice (Southard-Smith et al. 1999). Depending on the marker employed for the detection of melanoblasts, the decrease in numbers in heterozygous mice ranged from $50 \%-80 \%$. Given the minor pigmentation defects in adult mice, it appears that the loss of melanoblasts is at least in part compensated during further development.

In the homozygous Sox10 mutants, melanoblasts are very severely affected. We did not detect mi-, trp-2-, or Sox10-positive cells located subcutaneously, whereas few c-kit-positive cells remained. Hematopoietic precursor cells also express c-kit, and it is possible that the remaining c-kit-positive cells are not melanoblasts but of a different ontogenetic origin. Alternatively, a residual population of melanoblasts that expresses c-kit might exist, that is detected by none of the other markers employed here, that is, mi, trp-2, or Sox 10 . The presence of such melanoblasts would indicate that expression of $\mathrm{mi}$, trp-2, and Sox10 are controlled directly or indirectly by Sox10 in the melanoblast lineage. Additional experimental evidence indicates that $m i$ and trp-2 are Sox 10 target genes. The human MITF promoter is strongly activated by Sox10 in transient transfection experiments and contains multiple binding sites for Sox10 (Bondurand et al. 2000). Regulation of $\mathrm{mi}$ by Sox 10 can account for many aspects of the melanocyte defect seen in Sox10 mutant mice, as mi/MITF is a key regulator of melanocyte development (Goding 2000). We provide here evidence that trp-2 expression critically depends on Sox10 and that the trp-2 gene is a Sox10 target. First, trp-2-positive cells are reduced in numbers in heterozygous $\operatorname{Sox} 10^{1 a c Z}$ mice, and trp-2 mRNA levels are sensitive to Sox10 gene dosage. Second, transient transfection of the trp-2 promoter driving a reporter gene shows that the promoter is activated by Sox10. The setup of the transfection assay favors a model in which the regulation of trp-2 expression by Sox10 is direct. However, this remains to be proven by a further characterization of binding sites for Sox10 in the trp-2 promoter.

\section{Materials and methods}

Sox $10^{\text {lacz }}$ and Sox $10^{\text {Dom }}$ mutant mice

The Sox10 locus was isolated from a 129/Sv genomic $\lambda$ library. The targeting vector (Fig. 1a) was constructed by standard techniques. The linearized targeting vector was electroporated into $129 / \mathrm{Sv}$ R1 ES cells, which were selected with G418 and gancyclovir. Selected ES cell clones were screened for homologous recombination by PCR, which was confirmed by Southern hybridization using probes located $5^{\prime}$ and $3^{\prime}$ of the targeting vector (Fig. 1a,b; data not shown). Two independently targeted ES cell clones were used for injection into $\mathrm{C} 57 \mathrm{Bl} / 6 \mathrm{~J}$ blastocysts to generate chimeras and mutant mouse strains. No phenotypic differences were detected in mice derived from the two ES cell lines. Genotyping of mutant mice was performed by PCR.

The Sox $10^{\text {Dom }}$ allele spontaneously arose on a C57/Bl/ $6 \mathrm{~J} \times \mathrm{C} 3 \mathrm{HeB} / \mathrm{FeJ}$ hybrid background at the Jackson Laboratories (Lane and Liu 1984). Animals used here had a C57/Bl/ $6 \mathrm{~J} \times \mathrm{C} 3 \mathrm{HeB} / \mathrm{FeJ}$ mixed genetic background. The mice were genotyped by PCR using primers that amplify the D15Mit71 microsatellite, which generates a 14-bp polymorphism between $\mathrm{C} 57 \mathrm{BL} / 6 \mathrm{~J}$ and $\mathrm{C} 3 \mathrm{HeB} / \mathrm{FeJ}$. The Sox $10^{\text {Dom }}$ allele segregated with an 118-bp amplification product identical to that obtained with C57BL/6J genomic DNA.

$\beta$-galactosidase staining, in situ hybridization, immunohistology, and histology

Detection of $\beta$-galactosidase activity followed standard procedures: After fixation in $4 \%$ paraformaldehyde $(2 \mathrm{~h})$, embryos 
were incubated at $37^{\circ} \mathrm{C}$ in $1 \% \mathrm{X}$-gal $(1-6 \mathrm{~h})$. Whole-mount in situ hybridization was performed as described (Britsch et al. 1998). For generation of riboprobes the following plasmids were used: ErbB3, pDR3: EcoRI, 1.4-kb probe; Sox10, pZL1/SX10: NcoI, $\sim 1.3-\mathrm{kb}$ probe; Notch-1, pMN7: XbaI, $\sim 4-\mathrm{kb}$ probe; VAChT, pVAT2B: BamHI, 1.3-kb probe; c-kit, pGEM-ckit: EcoRI, $\sim 3.7-\mathrm{kb}$ probe; trp-2, p5A7: HindIII, $\sim 1.2$-kb probe; mi, pGEM-mi: NdeI, $\sim 1.2$-kb probe. For vibratome sectioning, embryos were embedded into $20 \%$ gelatine and fixed in $4 \%$ PFA. For immunohistological analysis, embryos were prefixed in $2 \%$ PFA and cryoprotected with $20 \%$ sucrose. Cryosections (10 um) were postfixed for 5-10 min with $2 \%$ PFA and blocked with $20 \%$ serum. The following antibodies were used: rabbit polyclonal anti-peripherin (Chemicon; 1:200), rabbit polyclonal anti-B-FABP (Kurtz et al. 1994; 1:5000), mouse monoclonal anti$\beta$-tubulin (clone TuJ-1; Covance; 1:500), mouse monoclonal anti-islet-1 (DSHB; clone 40.2 D6; 1:100), mouse monoclonal anti- $\beta$-galactosidase (Roche Biochemicals; 1:75), Cy2-conjugated anti-mouse IgG and Cy3-conjugated anti-rabbit IgG (Dianova; $1: 200)$. Sections were examined with a confocal microscope. For histological analysis, mouse embryos were fixed in $4 \%$ PFA at $4^{\circ} \mathrm{C}$, dehydrated and embedded in Technovit 7100 (Kulzer); $6 \mu \mathrm{m}$ sections were stained with haematoxilin/eosin. Motoneuron counts were performed as described previously (Woldeyesus et al. 1999).

Cell culture, RNA preparation, reverse transcription, PCR, and Northern blot

Stable transfectants of N2A neuroblastoma cells, which express rat Sox10, rat Sox11, or a mutant version of Sox10 under a doxycycline-inducible promoter were maintained as described (Kuhlbrodt et al. 1998b; Peirano et al. 2000). Sox gene expression was induced by the addition of $2.5 \mu \mathrm{g} / \mathrm{mL}$ doxycycline (Sigma) to the medium. Total RNA was isolated from N2A transfectants $10 \mathrm{~h}$ after the addition of doxycycline and reverse transcribed into cDNA as described (Peirano et al. 2000). For the quantification of ErbB3, cDNA was amplified with primer pairs specific for ErbB3, Sox10, Sox11, and GAPDH. The primer pair used for ErbB3 was 5'-GCGTTGCCAGTTGTCCCCATAA-3' and 5'-AGCGTCTCATAGCCCTTTTGTT-3'; the other primers and polymerase chain reactions conditions have been described (Peirano et al. 2000). Northern blotting was performed on $2 \mu \mathrm{g}$ of poly $(\mathrm{A})^{+}$RNA per sample using a 1150-bp mouse ErbB3 cDNA fragment.

Quantification of melanoblasts and trp-2-luciferase reporter assay

Numbers of melanoblasts were determined on sections of wildtype, heterozygous, and homozygous Sox10 lacZ embryos at E12.5 after in situ hybridization. Only cells in melanoblasttypical positions were counted. A total of 12 sections from 3 different embryos were counted for each genotype. Luciferase reporter genes under the control of the $3.7-\mathrm{kb}$ trp- 2 promoter (trp2luc), the $\mathrm{P}_{0}$ promoter (P0luc), or the thymidine kinase promoter (TKluc) as well as a reporter construct lacking a specific promoter (pGL2) were transfected into tet-on Neuro2A cells. Luciferase activity was measured before and after doxycycline treatment. Sox10-dependent promoter activation was expressed as the ratio between these two values.

\section{Acknowledgments}

We thank Cathrin Rudolph, Karin Gottschling, and Sven Buchert for expert technical assistance; Claus Stolt and Thomas
Franz for experimental support; and A. Garratt for help with the writing of the manuscript. Special thanks go to Henning Brohmann and $\mathrm{Li} \mathrm{Li}$ for supporting the project, to Martin Sieber for the statistical analysis, and Thomas Müller for the anti-B-FABP antibody. We obtained plasmids from the following scientists: p $75^{\text {NTR }}$ (L. Tessarollo and L. Reichardt), Notch-1 and Hes-5 (M. Hrabe de Angelis), Cadherin-6 (M. Takeichi), VAChT (D. Wolpowitz and J. Dedman), c-kit (M. Goossens), trp-2 and trp-2 promoter (I. Jackson). This work was supported by grants of the BMBF and DFG to C.B., M.W., and D.R.

The publication costs of this article were defrayed in part by payment of page charges. This article must therefore be hereby marked "advertisement" in accordance with 18 USC section 1734 solely to indicate this fact.

\section{References}

Adlkofer, K. and Lai, C. 2000. Role of neuregulins in glial cell development. Glia 29: 104-111.

Bondurand, N., Kuhlbrodt, K., Pingault, V., Enderich, J., Sajus, M., Tommerup, N., Warburg, M., Hennekam, R.C., Read, A.P., Wegner, M., et al. 1999. A molecular analysis of the yemenite deaf-blind hypopigmentation syndrome: SOX10 dysfunction causes different neurocristopathies. Hum. Mol. Genet. 8: 1785-1789.

Bondurand, N., Pingault, V., Goerich, D.E., Lemort, N., Sock, E., Caignec, C.L., Wegner, M., and Goossens, M. 2000. Interaction among SOX10, PAX3 and MITF, three genes altered in Waardenburg syndrome. Hum. Mol. Genet. 9: 1907-1917.

Britsch, S., Li, L., Kirchhoff, S., Theuring, F., Brinkmann, V., Birchmeier, C., and Riethmacher, D. 1998. The ErbB2 and ErbB3 receptors and their ligand, neuregulin-1, are essential for development of the sympathetic nervous system. Genes \& Dev. 12: 1825-1836.

Budd, P.S. and Jackson, I.J. 1995. Structure of the mouse tyrosinase-related protein-2/dopachrome tautomerase (Tyrp2/ Dct) gene and sequence of two novel slaty alleles. Genomics 29: $35-43$.

Epstein, D.J., Vekemans, M., and Gros, P. 1991. Splotch (Sp2H), a mutation affecting development of the mouse neural tube, shows a deletion within the paired homeodomain of Pax-3. Cell 67: 767-774.

Erickson, S.L., O'Shea, K.S., Ghaboosi, N., Loverro, L., Frantz, G., Bauer, M., Lu, L.H., and Moore, M.W. 1997. ErbB3 is required for normal cerebellar and cardiac development: A comparison with ErbB2-and heregulin-deficient mice. Development 124: 4999-5011.

Franz, T. and Kothary, R. 1993. Characterization of the neural crest defect in Splotch $(\mathrm{Sp} 1 \mathrm{H})$ mutant mice using a lacZ transgene. Brain Res. Dev. Brain Res. 72: 99-105.

Garratt, A.N., Britsch, S., and Birchmeier, C. 2000. Neuregulin, a factor with many functions in the life of a Schwann cell. BioEssays 22: 987-996.

Geissler, E.N., Ryan, M.A., and Housman, D.E. 1988. The dominant-white spotting (W) locus of the mouse encodes the c-kit proto-oncogene. Cell 55: 185-192.

Goding, C.R. 2000. Mitf from neural crest to melanoma: Signal transduction and transcription in the melanocyte lineage. Genes \& Dev. 14: 1712-1728.

Herbarth, B., Pingault, V., Bondurand, N., Kuhlbrodt, K., Hermans-Borgmeyer, I., Puliti, A., Lemort, N., Goossens, M., and Wegner, M. 1998. Mutation of the Sry-related Sox10 gene in Dominant megacolon, a mouse model for human Hirschsprung disease. Proc. Natl. Acad. Sci. 95: 5161-5165. Huang, E., Nocka, K., Beier, D.R., Chu, T.Y., Buck, J., Lahm, 
H.W., Wellner, D., Leder, P., and Besmer, P. 1990. The hematopoietic growth factor KL is encoded by the Sl locus and is the ligand of the c-kit receptor, the gene product of the $\mathrm{W}$ locus. Cell 63: 225-233.

Inoue, K., Tanabe, Y., and Lupski, J.R. 1999. Myelin deficiencies in both the central and the peripheral nervous systems associated with a SOX10 mutation. Ann. Neurol. 46: 313-318.

Jackson, I.J., Chambers, D.M., Tsukamoto, K., Copeland, N.G., Gilbert, D.J., Jenkins, N.A., and Hearing, V. 1992. A second tyrosinase-related protein, TRP-2, maps to and is mutated at the mouse slaty locus. EMBO J. 11: 527-535.

Jaegle, M., Mandemakers, W., Broos, L., Zwart, R., Karis, A., Visser, P., Grosveld, F., and Meijer, D. 1996. The POU factor Oct-6 and Schwann cell differentiation. Science 273: 507510.

Kageyama, R. and Nakanishi, S. 1997. Helix-loop-helix factors in growth and differentiation of the vertebrate nervous system. Curr. Opin. Genet. Dev. 7: 659-665.

Kapur, R.P. 1999. Early death of neural crest cells is responsible for total enteric aganglionosis in Sox10(Dom)/Sox10(Dom) mouse embryos. Pediatr. Dev. Pathol. 2: 559-569.

Kuhlbrodt, K., Herbarth, B., Sock, E., Hermans-Borgmeyer, I., and Wegner, M. 1998a. Sox10, a novel transcriptional modulator in glial cells. J. Neurosci. 18: 237-250.

Kuhlbrodt, K., Schmidt, C., Sock, E., Pingault, V., Bondurand, N., Goossens, M., and Wegner, M. 1998b. Functional analysis of Sox10 mutations found in human WaardenburgHirschsprung patients. J. Biol. Chem. 273: 23033-23038.

Kurtz, A., Zimmer, A., Schnutgen, F., Bruning, G., Spener, F., and Muller, T. 1994. The expression pattern of a novel gene encoding brain-fatty acid binding protein correlates with neuronal and glial cell development. Development 120: $2637-2649$.

Lane, P.W. and Liu, H.M. 1984. Association of megacolon with a new dominant spotting gene (Dom) in the mouse. J. Hered. 75: 435-439.

Le Douarin, N. and Kalcheim, C. 1999. The neural crest. Cambridge University Press, Cambridge, UK.

Meyer, D. and Birchmeier, C. 1995. Multiple essential functions of neuregulin in development Nature 378: 386-390.

Meyer, D., Yamaai, T., Garratt, A., Riethmacher-Sonnenberg, E., Kane, D., Theill, L.E., and Birchmeier, C. 1997. Isoformspecific expression and function of neuregulin. Development 124: 3575-3586.

Morris, J.K., Lin, W., Hauser, C., Marchuk, Y., Getman, D., and Lee, K.F. 1999. Rescue of the cardiac defect in ErbB2 mutant mice reveals essential roles of ErbB2 in peripheral nervous system development. Neuron 23: 273-283.

Morrison, S.J., Perez, S.E., Qiao, Z., Verdi, J.M., Hicks, C., Weinmaster, G., and Anderson, D.J. 2000. Transient Notch activation initiates an irreversible switch from neurogenesis to gliogenesis by neural crest stem cells. Cell 101: 499-510.

Peirano, R.I. and Wegner, M. 2000. The glial transcription factor Sox10 binds to DNA both as monomer and dimer with different functional consequences. Nucleic Acids Res. 28: 3047-3055.

Peirano, R.I., Goerich, D.E., Riethmacher, D., and Wegner, M. 2000. Protein zero gene expression is regulated by the glial transcription factor Sox10. Mol. Cell. Biol. 20: 3198-3209.

Pingault, V., Bondurand, N., Kuhlbrodt, K., Goerich, D.E., Prehu, M.O., Puliti, A., Herbarth, B., Hermans-Borgmeyer, K., Legius, E., Matthijs, G., et al. 1998. SOX10 mutations in patients with Waardenburg-Hirschsprung disease. Nat. Genet. 18: 171-173.

Pingault, V., Guiochon-Mantel, A., Bondurand, N., Faure, C., Lacroix, C., Lyonnet, S., Goossens, M., and Landrieu, P.
2000. Peripheral neuropathy with hypomyelination, chronic intestinal pseudo-obstruction and deafness: A developmental "neural crest syndrome" related to a SOX10 mutation. Ann. Neurol. 48: 671-676.

Pusch, C., Hustert, E., Pfeifer, D., Sudbeck, P., Kist, R., Roe, B., Wang, Z., Balling, R., Blin, N., and Scherer, G. 1998. The SOX10/Sox10 gene from human and mouse: Sequence, expression, and transactivation by the encoded HMG domain transcription factor. Hum. Genet. 103: 115-123.

Riethmacher, D., Sonnenberg-Riethmacher, E., Brinkmann, V., Yamaai, T., Lewin, G.R., and Birchmeier, C. 1997. Severe neuropathies in mice with targeted mutations in the ErbB3 receptor. Nature 389: 725-730.

Shah, N.M., Marchionni, M.A., Isaacs, I., Stroobant, P., and Anderson, D.J. 1994. Glial growth factor restricts mammalian neural crest stem cells to a glial fate. Cell 77: 349-360.

Southard-Smith, E.M., Kos, L., and Pavan, W.J. 1998. Sox10 mutation disrupts neural crest development in Dom Hirschsprung mouse model. Nat. Genet. 18: 60-64.

Southard-Smith, E.M.,Angrist, M., Ellison, J.S., Agarwala, R., Baxevanis, A.D., Chakravarti, A., and Pavan, W.J. 1999. The Sox10(Dom) mouse: Modeling the genetic variation of Waardenburg- Shah (WS4) syndrome. Genome Res. 9: 215225.

Topilko, P., Schneider-Maunoury, S., Levi, G., Baron-Van Evercooren, A., Chennoufi, A.B., Seitanidou, T., Babinet, C., and Charnay, P. 1994. Krox-20 controls myelination in the peripheral nervous system. Nature 371: 796-799.

Touraine, R.L., Attie-Bitach, T., Manceau, E., Korsch, E., Sarda, P., Pingault, V., Encha-Razavi, F., Pelet, A., Auge, J., Nivelon-Chevallier, A., et al. 2000. Neurological phenotype in Waardenburg syndrome type 4 correlates with novel SOX10 truncating mutations and expression in developing brain. Am. J. Hum. Genet. 66: 1496-1503.

Wakamatsu, Y., Maynard, T., and Weston, J.A. 2000. Fate determination of neural crest cells by NOTCH-mediated lateral inhibition and asymmetrical cell division during gangliogenesis. Development 127: 2811-2821.

Wegner, M. 1999. From head to toes: The multiple facets of Sox proteins. Nucleic Acids Res. 27: 1409-1420.

Weinmaster, G., Roberts, V.J., and Lemke, G. 1991. A homolog of Drosophila Notch expressed during mammalian development. Development 113: 199-205.

Woldeyesus, M.T., Britsch, S., Riethmacher, D., Xu, L., Sonnenberg-Riethmacher, E., Abou-Rebyeh, F., Harvey, R., Caroni, P., and Birchmeier, C. 1999. Peripheral nervous system defects in erbB2 mutants following genetic rescue of heart development. Genes \& Dev. 13: 2538-2548.

Wolpowitz, D., Mason, T.B., Dietrich, P., Mendelsohn, M., Talmage, D.A., and Role, L.W. 2000. Cysteine-rich domain isoforms of the neuregulin-1 gene are required for maintenance of peripheral synapses. Neuron 25: 79-91. 


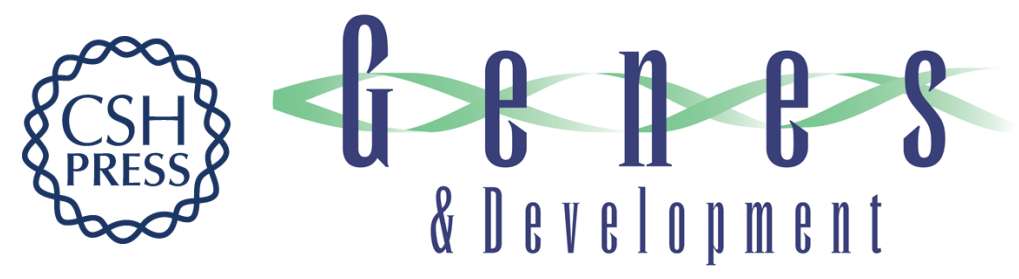

\section{The transcription factor Sox10 is a key regulator of peripheral glial development}

Stefan Britsch, Derk E. Goerich, Dieter Riethmacher, et al.

Genes Dev. 2001, 15:

Access the most recent version at doi:10.1101/gad.186601

$\begin{array}{ll}\text { References } & \text { This article cites } 42 \text { articles, } 14 \text { of which can be accessed free at: } \\ \text { http://genesdev.cshlp.org/content/15/1/66.full.html\#ref-list-1 }\end{array}$

License

Email Alerting Receive free email alerts when new articles cite this article - sign up in the box at the top Service right corner of the article or click here.

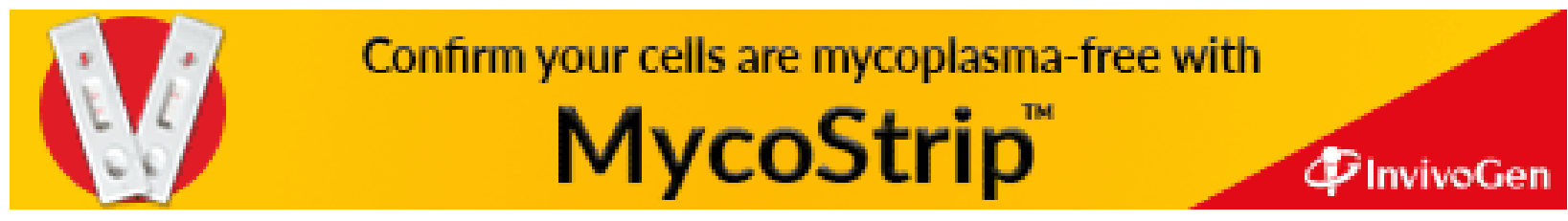

